\title{
Cultural Safety and Providing Care to Aboriginal patients in the Emergency Department
}

\author{
Evelyn M. Dell, MPH, MD*; Michelle Firestone, $\mathrm{PhD}^{\ddagger \S}$; Janet Smylie, MPH, MD ${ }^{\dagger \ddagger \S \pi}$; \\ Samuel Vaillancourt, MD, MPH $\|^{* *}$
}

\section{INTRODUCTION}

In July 2014, the United Nations Special Rapporteur on the rights of Indigenous peoples concluded that Canadian Aboriginal peoples face human rights problems of crisis proportions. ${ }^{1}$ The consequences of this are evident every day in many of Canada's emergency departments (EDs), yet the implications for ED patient care are not obvious. In a recent report, the Royal College of Physicians and Surgeons of Canada (RCPSC) stated, "[I]f the mainstream healthcare system in Canada is to be effective in helping to improve the health of First Nations, Inuit, and Métis clients, it must provide culturally safe care." ${ }^{2}$ EDs across the country treat the most acute manifestations of Aboriginal health inequities, manifested through disproportionate burdens of addiction, mental illness, physical trauma, chronic diseases, and infectious diseases. However, concepts related to cultural safety remain nebulous to most emergency physicians. The purpose of this paper is to present background and principles relevant to the practice of cultural safety in the ED.

\section{URBAN ABORIGINAL PEOPLES' HEALTH IN CANADA}

Cultural safety in health care for Aboriginal peoples refers to practices rooted in a basic understanding of Aboriginal peoples' beliefs and history and a process of self-reflection regarding the power differential existing between provider and patient that may affect the process of care and healing. ${ }^{3}$ The health inequities faced by many Aboriginal peoples today first took root in striking social, economic, and cultural trauma experienced throughout our collective history. The history of "residential schools," which spanned over one hundred years and lasted until 1996, is perhaps the most recognized example. ${ }^{1}$ A particularly distressing time was during "the Sixties Scoop," (1960-1980) during which time over 11,000 Aboriginal children were forced to leave their homes, ${ }^{4}$ placed in the child welfare system, and made to attend culturally foreign institutions with the stated goal of erasing their culture and family ties 5 . Though the last residential school closed in 1996, the disruption of Aboriginal families persists, and Aboriginal children continue to be significantly more likely to be in foster care compared to non-Aboriginal children. ${ }^{6}$ Though much positive work has been done to repair the relationship with Aboriginal peoples in Canada, ${ }^{1}$ the legacy of residential schools and colonial policies created deep intergenerational traumas and suspicion, the consequences of which remain visible today in many EDs. ${ }^{1,7,8}$ Furthermore, systemic racebased policies such as the federal Indian Act (which externally defines who is "Indian" and who is not), and marked inequities in the distribution of health and social resources continue to harm Aboriginal individuals and communities in Canada and undermine efforts of communities to govern themselves.

It is well documented that Aboriginal peoples in Canada suffer much higher rates of infectious diseases, ${ }^{9,10}$ chronic disease, ${ }^{11,12}$ and mental illness, ${ }^{13}$ all contributing to a significantly lower life expectancy. ${ }^{11,12,14,15}$ Evidence suggests health inequities are exacerbated among urban populations. ${ }^{14,16,17}$ Today, over $60 \%$ of Aboriginal

From the *Division of Emergency Medicine, Department of Medicine; tDalla Lana School of Public Health, University of Toronto, Toronto, ON; $\neq$ Centre for Research on Inner City Health; §Well Living House; đDepartment of Family and Community Medicine; \|Li Ka Shing Knowledge Institute; and **Department of Emergency Medicine, St. Michael's Hospital, Toronto, ON.

Correspondence to: Dr. Samuel Vaillancourt, Department of Emergency Medicine, St. Michael's Hospital, 30 Bond St, Toronto, ON M5B 1W8; Email: sam.vaillancourt@utoronto.ca 
peoples in Ontario reside in urban areas. ${ }^{18}$ While some have benefited from the rural to urban transition, ${ }^{19,20}$ many others have experienced marginalization, poverty, and housing insecurity. ${ }^{18,21-23}$ A recent study of Aboriginal peoples living in downtown Toronto found a mean age at death of 37 years, and linked most of these premature deaths to homelessness, physical violence, and substance use, exacerbated by poorly treated chronic conditions. $^{23}$

\section{URBAN ABORIGINAL PEOPLES AND THE ED}

Urban Aboriginal peoples are more likely to access ED care than the general population. A recent study of First Nations people living in Hamilton, Ontario, found that over $10 \%$ had more than six $\mathrm{ED}$ visits during the preceding two years, compared to $1.6 \%$ of overall Hamilton residents. ${ }^{22}$ Yet, $44 \%$ of First Nations people surveyed rated the quality of their ED care as fair or poor. ${ }^{24} \mathrm{~A}$ recent qualitative study in Vancouver found that during ED visits, Aboriginal patients often feel judged for being Aboriginal and living in poverty or presumed to be expressing illegitimate pain. ${ }^{25}$

In 2012, the Health Council of Canada held discussion groups with Aboriginal patients and their care providers who reported experiences of racism or stereotyping affecting the quality of ED care. One participant reported witnessing: "An Aboriginal man... was beaten and bloodied... he was not allowed to lie on a bed. When a physician asked why the patient was not lying down, the nurse explained that the man was dirty, and would just return to the street... to engage in the same risky behaviours that had landed him in emergency. In fact, the patient was employed, owned a home, and had been attacked on his way home from work." Other participants reported instances of missed or late diagnosis (e.g., diabetic ketoacidosis) arising from assumptions of addiction and intoxication. ${ }^{26}$ As frontline providers, ED health care providers are well-situated to intervene on inequities faced by Aboriginal patients. In the chaotic and risk-prone environment of the ED, cultural safety can help patients, their communities, and their health care providers.

\section{WHAT IS CULTURAL SAFETY?}

Cultural safety is usually seen as a continuum of knowledge, attitudes and behaviours that begins with cultural awareness. ${ }^{27}$ (Figure 1.) Culturally safe care involves understanding and acknowledging the power

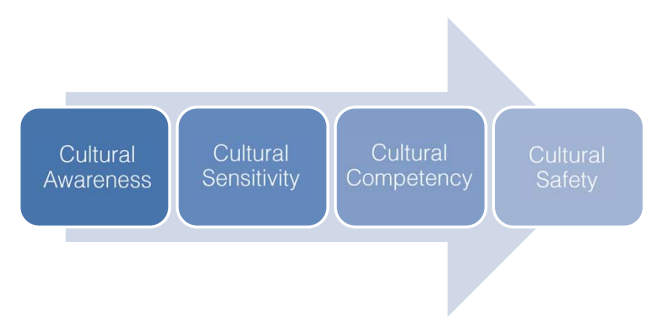

Figure 1. Continuum of Cultural Safety ${ }^{38}$

Cultural safety can be seen as a continuum of knowledge, attitudes and behaviours that begins with cultural awareness.

differential existing between provider and patient, ${ }^{7,28}$ and adjusting behaviour and services to empower and better meet patients' needs. ${ }^{29}$ In a recent analysis, Kumagai and Lypson stated that in order to adequately meet these needs, physicians must progress beyond cultural competency and develop a "critical consciousness" that views patients within a social, cultural and historical context, regardless of income, gender, or ethnicity. ${ }^{30}$ The RCPSC wrote that a culturally safe provider "practices critical thinking and self-reflection," and, in specific regard to Aboriginal peoples, "understands the unique historical legacies and intergenerational traumas affecting [their] health and fosters an understanding of [their] health values." " This process of recognizing our own biases minimizes the risk of cognitive errors that can affect diagnostic and therapeutic decisions. Critical self-reflection helps identify stereotypes that ultimately result in unsafe care.

The value and relevance of cultural safety principles extends beyond Aboriginal peoples. Cultural safety principles can be applied to the challenges faced by many groups in Canada whose health status and health care access has the potential to be compromised by historical and social context, discrimination, material deprivation, or power imbalances. Past experiences of alienation, perceived inequality, and maltreatment require sensitivity and compassion from health care providers. Trust and relationships are integral to the practice of cultural safety, and can be enhanced by the use of a language interpreter, a cultural broker, or by obtaining greater knowledge of the patient's culture or values.

Accessing health care involves potential harms as well as potential benefits. Iatrogenic injuries and nosocomial infections have been shown to harm thousands of patients every year in Canada. ${ }^{31}$ Similarly, health care can carry the risk of emotional and psychological harm. While medical care brings comfort for many, some patients receive care that makes them feel judged, 


\begin{tabular}{|c|c|}
\hline Principle & Possible Actions \\
\hline $\begin{array}{l}\text { The patient's way of knowing and being is } \\
\text { valid }\end{array}$ & $\begin{array}{l}\text { - Recognizing there are many ways of understanding and supporting health and well-being, } \\
\text { and that most patients do not draw on a strictly biomedical approach, care is enhanced } \\
\text { when perspectives are respected and bridged to allow for the patient's approach. } \\
\text { - Avoid assumptions regarding patient's desire to access or patient's knowledge of traditional } \\
\text { Indigenous medicines or ceremonies. } \\
\text { - Information from posters and/or notices on site to let patients know that traditional } \\
\text { - Indigenous medicines and ceremonies are respected and can be part of their care if desired. } \\
\text { Ensure respect of family, members of the patient's community or sacred items that patients } \\
\text { choose to involve in their care (e.g., drums, medicine bundles, pipes, tobacco, etc.) and } \\
\text { discuss their handling with patient and family. }\end{array}$ \\
\hline $\begin{array}{l}\text { The patient is a partner in the health care } \\
\text { decision-making process }\end{array}$ & $\begin{array}{l}\text { - Ensure patient or family understands what is happening and that resources and support are } \\
\text { available (e.g., traditional healers, patient advocates, clergy). } \\
\text { - Encourage and support patient and family, include them in all aspects of care and decision- } \\
\text { making and provide education as needed for informed decision making. }\end{array}$ \\
\hline $\begin{array}{l}\text { Recognize the impact of complex } \\
\text { intergenerational traumas on health and } \\
\text { access to health services }\end{array}$ & $\begin{array}{l}\text { - Reflect on how patient attitudes and behaviours that appear "challenging" to the health } \\
\text { care professional, might be ways of coping that have developed in response to complex } \\
\text { psychological trauma. } \\
\text { - Ensure non-judgmental and non-shaming communication. } \\
\text { - Develop self-awareness regarding compassion fatigue. }\end{array}$ \\
\hline $\begin{array}{l}\text { The patient determines whether or not the } \\
\text { care they have received is culturally safe }\end{array}$ & $\begin{array}{l}\text { - Work in partnership with the local Aboriginal community to optimize cultural safety in } \\
\text { the ED. } \\
\text { - Create designated space for Aboriginal patients in consultation with the Aboriginal } \\
\text { community when possible. } \\
\text { - Translate concepts of cultural safety into the predominant Indigenous languages of the area. }\end{array}$ \\
\hline
\end{tabular}

disempowered, or unimportant. As a result, old emotional wounds may unexpectedly arise-particularly with survivors of psychological trauma-as a consequence of culturally unsafe care.

\section{ABORIGINAL PATIENTS AND A CULTURALLY SAFE ED}

Cultural safety matters in the ED. Aboriginal peoples in Canada currently face a national health crisis. Cultural safety allows providers to create respectful alliances with patients to improve their health. ${ }^{2,29}$ A lack of cultural safety can reduce effective access to health services. ${ }^{28}$ It can also alienate patients, reduce adherence to treatment, exacerbate psychological trauma, and leave patients with a diminished sense of autonomy and empowerment (a factor known to be associated with care avoidance). ${ }^{25,26}$ Drawing on previous work in Canada and New Zealand, ${ }^{32-34}$ we propose four guiding principles and resulting possible actions to address cultural safety in ED care (Table 1).

Cultural safety is relevant to every person involved in ED patient care, from security personnel to nurses and physicians. The RCPSC emphasizes that cultural safety must be an important component of physicians' professional development and practice. ${ }^{3}$ The RCPSC's CanMEDS framework for post-graduate medical education has been very influential in shaping the development of specialist emergency medicine (EM) training programs over the past decade, unambiguously supporting critical thinking and self-reflective skills that promote cultural safety. The framework now specifically states that "the culturally competent physician embraces Indigenous knowledge," and "Indigenous health is an integral component of medical research, education, training and practice." $" 35$

Recent encouraging initiatives have advanced cultural safety in Canadian health care. For example, a First Nations Health Authority was recently created in British Columbia (BC) as part of a unique governance structure intended to enable First Nations people to take charge of the planning, management, delivery and funding of health programs. ${ }^{36}$ Another BC initiative recently created an online program on cultural competency for health care providers who work with Aboriginal patients. ${ }^{37}$ 
Emergency physicians are in a unique vantage point to witness the consequences of health disparities within our society. As a community, we have previously shown a great capacity for introspection and evolution in responding to health-related social issues, from the AIDS epidemic to intimate partner violence. At the same time, Aboriginal communities have demonstrated tremendous resilience in the face of economic and social obstacles, and organized themselves to bolster self-determination and well-being. In many communities across Canada, EDs represent a crucial point of access to care for Aboriginal patients. As a result, Canadian emergency physicians are ideally positioned to lead and take on the challenges of improving the cultural safety of ED care.

Competing Interests: Dr. Janet Smylie is supported by a Canadian Institute for Health Research Applied Public Health Research Chair. The authors do not have any other financial or other conflicts of interest to declare.

Keywords: Aboriginal health, emergency medicine, cultural safety, cultural competency

\section{REFERENCES}

1. United Nations Human Rights Council. Report of the Special Rapporteur on the rights of indigenous peoples: Extractive industries and indigenous peoples; 2013. Report No.: A/HRC/24/41. Available at: http://www.ohchr.org/EN/Issues/ IPeoples/SRIndigenousPeoples/Pages/SRIPeoplesIndex.aspx (accessed August 13, 2014).

2. Indigenous Physicians Association of Canada and the Royal College of Physicians and Surgeons of Canada. Cultural Safety in Practice: A Curriculum for Family Medicine Residents and Physicians. Winnipeg \& Ottawa: IPAC-RCPSC Family Medicine Curriculum Development Working Group; 2009. Available at: http://ipac-amic.org/wp-content/uploads/ 2011/10/CultSafetyinPractice_Family-Medicine.pdf.

3. Royal College of Physicians and Surgeons of Canada. Indigenous values, health and principles statement. The Indigenous Health Advisory Committee and the Office of Health Policy and Communications; 2013. Available at: http://www.royalcollege.ca/portal/page/portal/rc/common/ documents/policy/indigenous_health_values_principles_ report_e.pdf (accessed August 1, 2014).

4. Royal Commission on Aboriginal Peoples. The Report on the Royal Commission on Aboriginal Peoples; 1996. Available at: http://www.collectionscanada.gc.ca/webarchives/ 20071115053257/http://www.ainc-inac.gc.ca/ch/rcap/sg/ sgmm_e.html.

5. Johnston P. Native children and the welfare system. Ottawa, ON: Canadian Council on Social Development; 1983.

6. Statistics Canada. Aboriginal Peoples in Canada: First Nations People, Métis and Inuit. National Housebold Survey, 2011.
Catalogue no. 99-011-X201101. Ottawa, ON: Minister of Industry; 2013. Available at: http://www12.statcan.gc.ca/ nhs-enm/2011/as-sa/99-011-x/99-011-x2011001-eng.pdf (accessed January 19, 2014).

7. Brascoupé S, Waters C. Cultural safety. Exploring the applicability of the concept of cultural safety to Aboriginal health and community wellness. 7 Aborig Health 2009;5(2): 6-41.

8. Felitti V, Anda R, Nordenberg D, et al. Relationship of childhood abuse and household dysfunction to many of the leading causes of death in adults: The Adverse Childhood Experiences (ACE) Study. Am 7 Prev Med 1998;14(4):245-58.

9. Morrisseau K. Aboriginal cancer control progress report. Aboriginal Services, 2009. Available at: http://www. cancercare.mb.ca/resource/File/Aboriginal_CancerControl ProgressReport_07-08.pdf (accessed January 19, 2014).

10. Health Canada. A Statistical Profile on the Health of First Nations in Canada: Self-rated Health and Selected Conditions, 2002 to 2005. Ottawa; 2009. Report No.: H34-193/22008E-PDF. Available at: http://www.hc-sc.gc.ca/fniah-spnia/ pubs/aborig-autoch/2009-stats-profil-vol3/index-eng.php.

11. Adelson N. The embodiment of inequity: health disparities in aboriginal Canada. Can $\mathcal{F}$ Public Health 2005;96(Suppl 2): S45-61.

12. Lix L, Bruce S, Sarkar J, et al. Risk factors and chronic conditions among aboriginal and non-aboriginal populations. Health Rep 2009;20(4):21-9.

13. Statistics Canada. Canadian Community Health Survey: First Nations Information Governance Committee. First Nations Regional Longitudinal Health Survey 2002/03; Results for Adults, Youth and Children Living in First Nations Communities. First Nations Centre; 2005. Available at: http://fnigc.ca/sites/default/files/ENpdf/RHS_2002/ rhs2002-03-technical_report.pdf.

14. Tjepkema M, Wilkins R, Senécal S, et al. Mortality of urban Aboriginal adults in Canada, 1991-2001. Chronic Dis Can 2010;31(1):4-21.

15. Young TK. Review of research on aboriginal population in Canada: relevance to their health needs. BMF 2003; 327(7412):419-22.

16. Shah C, Ramji F. Health Status Report of Aboriginal People in Ontario. Toronto: Anishnawbe Health; 2014. Available at: http://www.aht.ca/images/stories/NEWS-RESOURCES/ RESEARCH/HlthStatusAboEdFinal1.pdf (accessed May 1, 2014).

17. Statistics Canada. Aboriginal Peoples Survey 2001 - Initial Findings: Well-being of the Non-reserve Aboriginal Population (89-592-X). Statistics Canada; 2003. Available at: http://www5.statcan.gc.ca/olc-cel/olc.action?ObjId=89-589$X \& O b j$ Type $=2 \&$ lang $=$ en $\&$ limit $=0$ (accessed May 1, 2014).

18. Statistics Canada. Aboriginal Peoples in Canada in 2006: Inuit, Métis and First Nations, 2006 Census. Ottawa: Ministry of Industry; 2008. Available at: http://www12.statcan.ca/censusrecensement/2006/as-sa/97-558/pdf/97-558-XIE2006001.pdf.

19. Environics Institute. Urban Aboriginal Peoples Study Main Report. Environics Institute; 2010. Available at: http://www. uaps.ca/.

20. McCaskill D, FitzMaurice K, Cidro J. Toronto Aboriginal Research Project (TARP) Final Report; 2011. Available at: http://www.councilfire.ca/Acrobat/tarp-final-report2011.pdf. 
21. Garner R, Carrière G, Sanmartin C. Longitudinal Health and Administrative Data Research Team. The Health of First Nations Living Off-reserve, Inuit, and Métis adults in Canada: The Impact of Socio-economic Status on Inequalities in Health. Ottawa: Statistics Canada, Health Analysis Division; 2010. Report No.: 82-622-X. Available at: http://www.statcan.gc.ca/pub/82-622-x/82-622-x2010004eng.pdf.

22. Firestone M, Smylie J, Maracle S, et al. Unmasking health determinants and health outcomes for urban First Nations using respondent-driven sampling. BM7 Open 2014;4: e004978. Available at: http://bmjopen.bmj.com/content/ 4/7/e004978.abstract (accessed August 1, 2014).

23. Shah C, Klair R, Reeves A. Early death among members of Toronto's Aboriginal Community: Walking in their shoes. Toronto: Anishnawbe Health Toronto; 2014. Available at: http://www.toronto.ca/legdocs/mmis/2013/hl/bgrd/ backgroundfile-64668.pdf (accessed May 1, 2014).

24. Smylie J, Firestone M, Cochran L, et al. Our Health Counts (OHC): Urban Aboriginal Health Database Research Project. Community Report. Hamilton, ON: First Nations Adults and Children; 2011. Available at: http://www.stmichaelshospital. com/crich/wp-content/uploads/our-health-counts-report.pdf (accessed January 19, 2014).

25. Browne AJ, Smye VL, Rodney P, et al. Access to primary care from the perspective of Aboriginal patients at an urban emergency department. Qual Health Res 2011; 21(3):333-48.

26. Health Council of Canada. Empathy, Dignity, and Respect: Creating Cultural Safety for Aboriginal People in Urban Health Care - Report; 2012. Available at: http:// www.healthcouncilcanada.ca/rpt_det.php?id=437 (accessed November 1, 2014).

27. Ramsden I. Kawa Whakarurubau: Guidelines for Nursing and Midwifery Education. Wellington, NZ: Nursing Council of New Zealand; 1992.

28. Indigenous Physicians Association of Canada and the Royal College of Physicians and Surgeons of Canada (IPAC \& RCPSC). First Nations, Inuit, Métis health core competencies: A Curriculum Framework for Continuing Medical Education; 2009. Available at: http://postgrad.familymed. ubc.ca/files/2012/05/IPAC-Core-PGME-Comp.pdf.
29. Peiris D, Brown A, Cass A. Addressing inequities in access to quality health care for indigenous people. CMAJ 2008;179(10):985-6.

30. Kumagai AK, Lypson ML. Beyond cultural competence: critical consciousness, social justice, and multicultural education. Acad Med 2009;84(6):782-7.

31. Baker GR, Norton PG, Flintoft V, et al. The Canadian Adverse Events Study: the incidence of adverse events among hospital patients in Canada. CMAJ 2014;170(11):1678-86.

32. National Aboriginal Health Organization (NAHO). Cultural Competency and Safety: A Guide for Health Care Administrators, Providers and Educators. Ottawa: National Aboriginal Health Organization; 2008. Available at: www.naho.ca/publications/ culturalCompetency.pdf (accessed August 1, 2014).

33. DeSouza R. Wellness for all: the possibilities of cultural safety and cultural competence in New Zealand. 7 Res Nurs 2008;13(2):125-35.

34. Allan B, Smylie J. First Peoples, Second Class Treatment: The role of racism in the bealth and well-being of Indigenous peoples in Canada. Toronto, ON: The Wellesley Institute; 2015. Available at: http://www.wellesleyinstitute.com/wp-content/ uploads/2015/02/Report-First-Peoples-Second-ClassTreatment-Final.pdf (accessed April 2, 2015).

35. Royal College of Physicians and Surgeons of Canada (RCPSC). Progress promoting culturally-safe care for Indigenous Peoples. Dialogue Newsletter 2013;14:6. Available at: http://www.royalcollege.ca/portal/page/portal/rc/resources/publications/dialogue/vol14_6/indigs.

36. First Nations Health Authority. Governance and Accountability; 2014. Available at: http://www.fnha.ca/about/governance-and-accountability (accessed November 1, 2014).

37. Provincial Health Services Authority British Columbia. Indigenous Cultural Competency Training Program; 2014. Available at: http://www.culturalcompetency.ca/home (accessed November 1, 2014).

38. National Collaborating Centre for Aboriginal Health (NCCAH). Towards cultural safety for Métis: An introduction for health care providers. Métis Centre of the National Aboriginal Health Organization; 2013. Available at: http:// www.nccah-ccnsa.ca/en/publications.aspx? sortcode $=2.8 .10 \&$ publication=76 (accessed August 19, 2014). 